\title{
Actions and achievements of self-regulated learning in personal environments. Research on students participating in the Graduate Program in Preschool Education at the University of Granada
}

\author{
Eduardo Chaves-Barboza1* (1), Juan Manuel Trujillo-Torres² (0), Juan Antonio López- \\ Núñez ${ }^{3}$ (i), Tomás Sola-Martínez $z^{4}$ \\ 'Department of Teaching and School Organization, National University of Costa Rica, Heredia, Costa Rica \\ \{echav@una.cr\} \\ 2Department of Teaching and School Organization, University of Granada, Granada, Spain \{jtorres@ugr.es\} \\ ${ }^{3}$ Department of Teaching and School Organization, University of Granada, Granada, Spain \{juanlope@ugr.es\} \\ ${ }^{4}$ Department of Teaching and School Organization, University of Granada, Granada, Spain \{tsola@ugr.es\}
}

Received on 15 February 2017; revised on 21 March 2017; accepted on 5 April 2017; published on 15 July 2017

DOI: 10.7821/naer.2017.7.236

(c) BY-NC-ND

\begin{abstract}
This paper is intended to study the self-regulated learning (SRL) process in personal learning environments (PLEs) among students participating in the Graduate Program for Preschool Education at the University of Granada (Spain). The study is focused on self-regulatory actions carried out by students, and on their self-regulated learning achievements, during the phases of action and reflection of this process.

A Likert scale questionnaire was applied to a random cluster sample of the population. Descriptive and inferential statistical analyses were performed based on the collected data, as were non-parametric correlation and analysis of variance tests.

The results confirm the importance of individual learning in the self-regulated process, and highlight the importance of digital tools in all three phases of self-regulation. Furthermore, the results show that teachers' suggestions are related to the use of digital tools and recording of reflections on the learning process, and establish relationships between learning management tools and cognitive and metacognitive processes. The results also permit classification of students into three subgroups, based on their achievements. Analyses are consistent with the theory that explains the cyclical nature of self-regulated learning and the influence of social relationships on individual self-regulatory processes.
\end{abstract}

KEYWORDS: SELF-REGULATED LEARNING, LEARNING ENVIRONMENT, TEACHER EDUCATION, PRESCHOOL EDUCATION

\section{INTRODUCTION}

\subsection{Self-regulated learning (SRL)}

According to the socio-cognitive approach, self-regulated learning consists of a cycle with three phases -forethought, performance control, and reflection (Schunk \& Zimmerman, 2003;

*To whom correspondence should be addressed: Universidad Nacional, Campus Omar Dengo. Heredia, Costa Rica. Avenida 1, Calle 9. Apartado Postal: 86-3000
Usher \& Pajares, 2008; Zimmerman \& Cleary, 2009; Zimmerman \& Schunk, 1989).

In theory, this cyclical process is based on four assumptions: the first one is that learners are active in constructing their own goals and meanings based on their own internal cognitive system, influenced by a certain environment; the second is that individuals are able to control and monitor the cognitive, motivational and behavioral elements of their learning; the third is that self-regulated learning depends on and is facilitated by individual factors such as biological, emotional and cognitive factors, as well as by external or environmental factors; and finally, it is assumed that individuals are able to evaluate their own learning objectives, monitor their behavior and cognitive processes, and use the results of this evaluation to regulate their own learning.

In the phase of forethought, individuals select their learning goals and carry out strategic planning to achieve these goals. On the one hand, individuals have previous knowledge to assist in carrying out these actions. However, performance of these actions is highly influenced by individuals' self-perceptions: their own motivation, efficacy, and expectations for learning. Individual learners must not only know strategies for self-regulating their learning, but they must also trust in their own ability to carry out their strategies successfully.

In the performance phase, also known as the phase of volitional control, individuals apply the strategies they established in the first phase, and perform tasks to accomplish their learning goals. This phase involves self-control and self-observation, since during performance individuals control their own motivation, monitor their efficacy, and observe the achievement of their learning goals (Hadwin, Oshige, Gress, \& Winne, 2010; Jin \& Low, 2009)

In the last phase, reflection, individuals carry out self-evaluation and self-judgment: they use what they observed during the previous phase, and take advantage of their previous experiences for feedback and decision-making. In this phase, individuals modify their behaviors, adjust their strategies, and prepare to restart the cycle to self-regulate their learning.

The theory of self-regulated learning (SRL) emphasizes individuals' management abilities; however, it also acknowledges that the process as a whole takes place within a social environment. 
This means that actions such as regulating their own behaviors, monitoring their cognitive achievements, and adjusting their strategies, take place under the influence of, and with the participation of, other learners, teachers, experts, and an entire social network (Bullock, 2013; Chatti et al. 2013; Cheng \& Chau, 2013; Cho \& Cho, 2013; Holt \& Brockett, 2012; Ros et al., 2013). As shown in this article, these characteristics make the self-regulated learning theory especially useful for investigating educational processes in Personal Learning Environments (PLEs).

\subsection{Personal learning environments (PLEs)}

The idea of PLEs is a theoretical-pedagogical conceptual construction created by a community of technologists and teachers seeking to interpret the impact of Web 2.0 technologies on the learning of individuals. PLEs are conceived of as the set of technological tools selected, integrated and used by an individual to access new sources of knowledge and making use of them to learn (Buchem \& Tur, 2014; Fiedler \& Väljataga, 2011; Fiedler \& Väljataga, 2013; Valtonen et al., 2012).

Both theorists and researchers agree on the tight relationship between PLEs and self-regulated learning abilities. It has been frequently stated that an efficient, personalized and satisfactory PLE is a positive factor that assists individuals to set their learning goals, look for and organize content, communicate with other persons, and evaluate their own learning actions (Archee, 2012; Chaves, Trujillo, \& López, 2015; Chaves, Trujillo, \& López, 2016; Dabbagh \& Kitsantas, 2012; Ebner \& Taraghi, 2010; Johnson \& Sherlock, 2014).

\subsection{Study objectives}

The general objective of this work is to analyze the actions carried out by students working towards a Graduate Degree in Preschool Education (whose acronym in Spanish is GEI) in the University of Granada (UGR), Spain, as well as their achievements during their self-regulated learning process. The analysis is focused on the phases of performance and reflection in their PLEs.

Five specific objectives are proposed for reaching the general objective. The first of these is to establish self-regulated actions for learning that GEI students carry out in their PLEs during the phases of performance and reflection; the second is to correlate these actions; the third is to determine achievements in self-regulated learning reached by GEI students in the phases of performance and reflection; the fourth objective is to correlate these achievements; and the fifth is to study the influence of these actions on achievements.

\subsection{Importance of the study}

This study provides students with knowledge about their PLEs and assistance in constructing them. In fact, researchers and theorists in the area of PLEs indicate the importance of studying and evaluating the entire process involved in student PLEs, since this environment is better developed when conscientious and self-regulated use of its tools occurs, and even more so if there is support by classmates, teachers and other actors in the educational community (Archee, 2012; Dabbagh \& Kitsantas, 2012).

Empirical studies of this sort are likewise valuable for students because they allow them to better understand their own self-regulatory efficacy, serving as a catalyst for the self-regulated learning cycle to proceed successfully (Jin \& Low, 2009; Usher \& Pajares, 2008; Zimmerman, 2008).
Finally, the pedagogical elements studied in this work are highly interesting for those in charge of the GEI and for all academicians involved in teaching, research, or management of similar programs.

\section{METHODOLOGY}

\subsection{Population and sample}

The population studied consists of UGR GEI students who were active during the period of the investigation. In total, the population had 877 subjects ( 829 women and 48 men), divided into 14 groups of students ( 5 in the first level, 5 in the second level, and 4 in the third level). A framework of clusters was constructed within these groups to permit the random selection of a sample made up of 12 groups and 520 students.

During May and June 2013 a questionnaire was applied to this sample of students, permitting confidence intervals of 95\% (CI 95\%) for study results.

\subsection{Questionnaire}

The questionnaire includes some initial questions about general aspects such as gender, age, hours per week dedicated to different activities (for instance, navigating on the Internet, or using PLE tools); there are also questions about access to devices for personal use (desktop computers, tablets and smart phones, among others). These are called general items.

The main questions refer firstly to actions carried out by students to self-regulate learning in their PLEs (16 items) and, secondly, to achievements obtained through self-regulation (12 items). These questions were presented using a four-option Likert scale (Strongly disagree; Disagree; Agree; Strongly agree), and are called main items.

\subsection{Variables, tests and hypothesis}

The questionnaire's general items are general variables, including a dichotomic variable and six ratio-level variables; the standard error of the mean (SEM) was calculated for the ratio variables at 95\% confidence level (Strahan, 1982). The general variables are used in the study for describing the population. The main items are associated with 28 four-level ordinal variables, referred to as main variables because they are analyzed to determine compliance with the objectives.

Descriptive and inferential statistics analyses were carried out on the main variables of the questionnaire to comply with the first and third objectives, determining the actions taken by students and their achievements in self-regulated learning.

Non-parametric correlation tests -specifically, Kendall's coefficient- were applied to comply with the second and fourth objectives, (Leech, Barrett, \& Morgan, 2011). The hypotheses proposed in these tests are the usual ones in correlation tests; each null hypothesis is that the correlation coefficient between two variables is zero, and each alternative hypothesis assumes that it is different than zero. Kendall's coefficient calculates a correlation coefficient for each pair of self-regulatory actions students carry out in their PLEs; these coefficients are ordered in a correlation matrix. Student achievements are processed in the same way.

Kruskal-Wallis analyses of variance (Kruskal \& Wallis, 1952) were carried out to determine the influence of self-regulated actions on each one of the self-regulation achievements. Accordingly, for each action-achievement a null and an alternative hypothesis were proposed; i.e., the hypothesis of equality of all 
the measurements in the dependent achievement variable for different levels of the independent action variable, and the hypothesis of non-equality, respectively. The extent of the effect is calculated and analyzed in each analysis of variance test (Cohen, 1992) with $95 \%$ confidence level (SE 95\%).

Both the Kendall's coefficient (Leech, Barrett, \& Morgan, 2011) and Kruskal-Wallis tests were carried out with a two-tailed significance of $95 \%$.

\subsection{Questionnaire validity and reliability}

This questionnaire was validated by ten educational technology experts, with all items having an Osterlind concordance index (Osterlind, 1989) greater than 0.5, indicating that the instrument is valid. Statistic reliability was also analyzed using Cronbach's alpha coefficient; the alpha value for the instruments was 0.92 , indicating excellent reliability.

\section{RESULTS OF THE STUDY TESTS}

\subsection{Population characteristics}

As shown in Figure 1, the most popular device used by the students in the population is the portable computer, followed by smart phones. The percentage of students with a desktop computer available for personal use was half of that for portable computers.

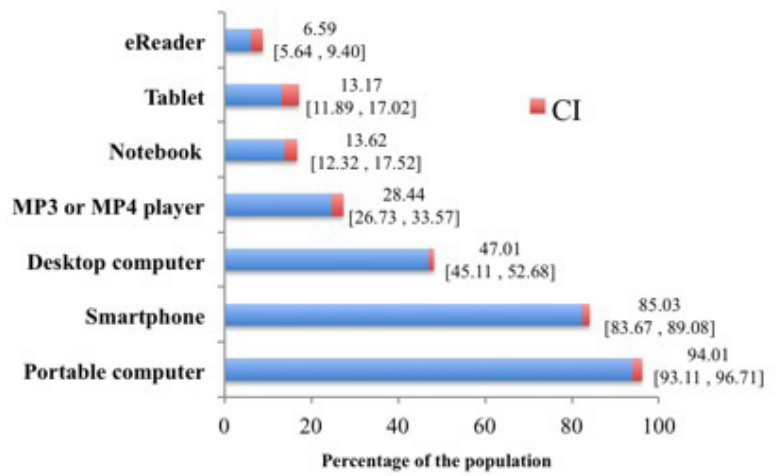

Figure 1. Relative numbers of students, with $95 \%$ confidence intervals, by device available for personal use

The sample used in the study was $97.69 \%$ female, and $1.29 \%$ male, with a sample error of less than $5 \%$. Average age was 23.45 \pm 0.14 years $(\mathrm{SEM}=0.07)$. The population spent $17.30 \pm 0.44$ hours per week $(\mathrm{SEM}=0.22)$ navigating on the Internet, $18.28 \pm 0.36$ hours (SEM=0.18) using the tools in their PLEs, and $7.08 \pm 0.31$ hours $(\mathrm{SEM}=0.16)$ visiting a platform on the University's network.

\subsection{Actions for self-regulated learning in PLEs}

Table 1 presents the frequencies of the actions carried out by students in their PLEs during the performance phase. As should be the case in this self-regulated learning phase, these actions were those taken by students to achieve their learning goals.

Based on this Table, it may be concluded that during the performance phase students were able to adapt Learning Management System (LMS) tools to their learning goals, and integrate their tools into their PLEs. Although the idea of PLE emerged and gained support based on criticisms of LMS and the underlying traditional educational approach, it is clear from these results that an institutional LMS may be the PLE tool for university students.

Figure 2 summarizes the results of Table 1, showing that students use both LMS and other tools from outside the University to exchange information with classmates. External tools stand out for the intensity with which they were used (53.46\%), and by the extent to which they were used $(64.42 \%)$ above all other tools. This indicates that students preferred tools from outside the University for exchanging information with classmates, rather than those offered through the University's LMS. It is also clear that students used their PLE tools to send and receive information from other non-classmates.

Course teachers are an important part of students' learning environment; students asked for their support and showed critical thinking about their teaching strategies during the performance phase. In addition, as shown in Table 2, students valued their evaluations and suggestions for improving their work during the reflection phase.

Table 2 shows that during the third self-regulation phase, students recorded their reflection on learning, and organized these thoughts with digital tools in their PLEs.

\subsection{Relationships between actions for self-regulated learning in PLEs}

The data was consistent in showing that in both the performance and the reflection phase, slightly over half of the students documented their personal learning process and recorded their thoughts about it; i.e., the two actions coincided in terms of frequencies. As shown in Table 3, these two actions were also significantly correlated, indicating that there was a student subgroup who recorded their learning process and thoughts about this process. Further investigations could provide more information about details of this subgroup of students.

The correlations matrix presented in Table 3 shows that teacher evaluations and recommendations for improving student work were related to student reflections about their own learning and use of digital tools to present their ideas in several ways. This indicates that teachers had possibly made suggestions and evaluations about the use of digital tools and metacognitive reflection to help improve student work.

Likewise, student actions related to organizing reflections about learning using digital tools were strongly correlated with actions of reflecting on their own role on their learning, and on recording their reflections during their own learning. The last two were also significantly related to each other. This means that actions during the reflection phase were supported by PLE digital tools during the thinking process itself, as well as during the organization and recording of the process.

It should be noted that there were significant correlations between recording reflections on self-learning, using a personal blog to delve into ideas or concepts, documenting the personal learning process, and adapting some university LMS platform tools to learning goals.

As shown in Table 3, the action of using tools from outside the University environment for exchanging information with classmates was significantly correlated with the use of university LMS tools for sending and receiving information. For their part, the use of PLE tools to send information to persons who were not participating in the course had a significant correlation with the use of external tools for exchanging information with persons that were participating in the course. 
Table 1. Actions for self-regulated learning in PLEs, performance phase

\begin{tabular}{|c|c|c|c|c|c|}
\hline \multirow{2}{*}{ Actions } & \multicolumn{4}{|c|}{ Relative frequencies with confidence intervals ${ }^{(1)}$} & \multirow{2}{*}{$\begin{array}{c}\% \\
\mathrm{NA}^{(2)}\end{array}$} \\
\hline & Strongly disagree & Disagree & Agree & Strongly agree & \\
\hline $\begin{array}{l}\text { Using tools from outside the University for exchanging infor- } \\
\text { mation with classmates }\end{array}$ & $\begin{array}{c}2.50 \\
{[1.18,3.82]}\end{array}$ & $\begin{array}{c}6.54 \\
{[4.45,8.63]}\end{array}$ & $\begin{array}{c}34.23 \\
{[30.26,38.21]}\end{array}$ & $\begin{array}{c}53.46 \\
{[49.33,57.60]}\end{array}$ & 3.27 \\
\hline $\begin{array}{l}\text { Using tools of a University LMS platform to send information } \\
\text { to classmates }\end{array}$ & $\begin{array}{c}2.50 \\
{[1.18,3.82]}\end{array}$ & $\begin{array}{c}8.46 \\
{[6.11,10.81]}\end{array}$ & $\begin{array}{c}50.77 \\
{[46.62,54.92]}\end{array}$ & $\begin{array}{c}35.00 \\
{[31.00,39.00]}\end{array}$ & 3.27 \\
\hline Using digital tools to represent ideas in various forms & $\begin{array}{c}1.15 \\
{[0.25,2.06]}\end{array}$ & $\begin{array}{c}10.0 \\
{[7.47,12.53]}\end{array}$ & $\begin{array}{c}50.58 \\
{[46.43,54.72]}\end{array}$ & $\begin{array}{c}34.81 \\
{[30.82,38.79]}\end{array}$ & 3.46 \\
\hline $\begin{array}{l}\text { Using tools of any University LMS platform to receive infor- } \\
\text { mation from classmates }\end{array}$ & $\begin{array}{c}2.12 \\
{[0.90,3.33]}\end{array}$ & $\begin{array}{c}10.77 \\
{[8.16,13.38]}\end{array}$ & $\begin{array}{c}53.27 \\
{[49.14,57.40]}\end{array}$ & $\begin{array}{c}30.38 \\
{[26.53,34.24]}\end{array}$ & 3.46 \\
\hline Asking for support from the course teacher & $\begin{array}{c}1.54 \\
{[0.50,2.57]}\end{array}$ & $\begin{array}{c}11.54 \\
{[8.86,14.22]}\end{array}$ & $\begin{array}{c}57.31 \\
{[53.26,61.35]}\end{array}$ & $\begin{array}{c}25.58 \\
{[21.93,29.22]}\end{array}$ & 4.04 \\
\hline $\begin{array}{l}\text { Using PLE tools to send information to persons not participat- } \\
\text { ing in the course }\end{array}$ & $\begin{array}{c}4.23 \\
{[2.54,5.92]}\end{array}$ & $\begin{array}{c}23.08 \\
{[19.55,26.60]}\end{array}$ & $\begin{array}{c}43.27 \\
{[39.17,47.37]}\end{array}$ & $\begin{array}{c}25.38 \\
{[21.75,29.02]}\end{array}$ & 4.04 \\
\hline $\begin{array}{l}\text { Using PLE tools for receiving information from persons not } \\
\text { participating in the coursea }\end{array}$ & $\begin{array}{c}5.38 \\
{[3.48,7.29]}\end{array}$ & $\begin{array}{c}26.54 \\
{[22.84,30.24]}\end{array}$ & $\begin{array}{c}41.92 \\
{[37.82,46.03]}\end{array}$ & $\begin{array}{c}22.50 \\
{[19.00,26.00]}\end{array}$ & 3.65 \\
\hline $\begin{array}{l}\text { Showing critical thinking about the teaching strategies used by } \\
\text { the teacher }\end{array}$ & $\begin{array}{c}1.54 \\
{[0.50,2.58]}\end{array}$ & $\begin{array}{c}16.73 \\
{[13.59,19.87]}\end{array}$ & $\begin{array}{c}59.42 \\
{[55.39,63.46]}\end{array}$ & $\begin{array}{c}18.85 \\
{[15.56,22.14]}\end{array}$ & 3.46 \\
\hline Adding tools of some University LMS platforms to the PLE & $\begin{array}{c}4.04 \\
{[2.38,5.70]}\end{array}$ & $\begin{array}{c}23.27 \\
{[19.73,26.81]}\end{array}$ & $\begin{array}{c}55.19 \\
{[51.11,59.28]}\end{array}$ & $\begin{array}{c}13.65 \\
{[10.77,16.54]}\end{array}$ & 3.85 \\
\hline Documenting the personal learning process & $\begin{array}{c}8.08 \\
{[5.79,10.36]}\end{array}$ & $\begin{array}{c}32.50 \\
{[28.60,36.40]}\end{array}$ & $\begin{array}{c}49.62 \\
{[45.50,53.73]}\end{array}$ & $\begin{array}{c}5.58 \\
{[3.65,7.50]}\end{array}$ & 4.23 \\
\hline $\begin{array}{l}\text { Adapting the tools of some University LMS platforms to } \\
\text { learning goals }\end{array}$ & $\begin{array}{c}6.92 \\
{[4.78,9.06]}\end{array}$ & $\begin{array}{c}32.31 \\
{[28.40,36.22]}\end{array}$ & $\begin{array}{c}50.58 \\
{[46.44,54.71]}\end{array}$ & $\begin{array}{c}6.54 \\
{[4.46,8.62]}\end{array}$ & 3.65 \\
\hline $\begin{array}{l}\text { Using a personal blog to delve into ideas or concepts of the } \\
\text { course }\end{array}$ & $\begin{array}{c}25.19 \\
{[21.56,28.82]}\end{array}$ & $\begin{array}{c}45.96 \\
{[41.84,50.08]}\end{array}$ & $\begin{array}{c}20.38 \\
{[17.01,23.76]}\end{array}$ & $\begin{array}{c}4.42 \\
{[2.69,6.15]}\end{array}$ & 4.04 \\
\hline
\end{tabular}

In this Table, $\mathrm{N}=877,(1) \mathrm{CI} 95 \%$ and (2) $\mathrm{NA}=$ No answer

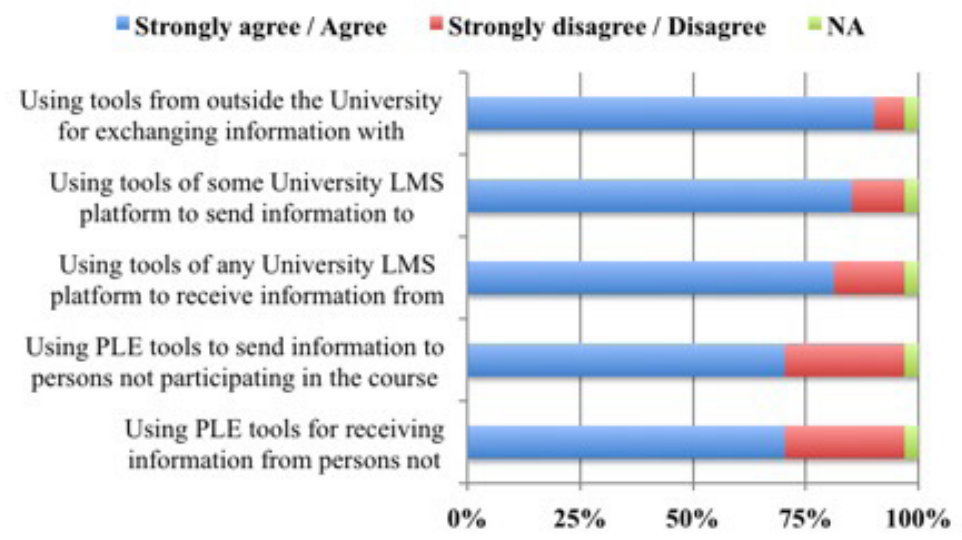

Figure 2. Actions for complying with goals during the performance phase 
Table 2. Actions for self-regulated learning in PLEs, reflection phase

\begin{tabular}{|c|c|c|c|c|c|}
\hline \multirow{2}{*}{ Actions } & \multicolumn{4}{|c|}{ Frecuencias relativas con intervalos de confianza ${ }^{(1)}$} & \multirow{2}{*}{$\begin{array}{c}\% \\
\mathrm{NA}^{(2)}\end{array}$} \\
\hline & Strongly disagree & Disagree & Agree & Strongly agree & \\
\hline Valuing teacher evaluations or suggestions for improving work & $\begin{array}{c}0.77 \\
{[0.03,1.51]}\end{array}$ & $\begin{array}{c}8.08 \\
{[5.78,10.37]}\end{array}$ & $\begin{array}{c}63.46 \\
{[59.55,67.38]}\end{array}$ & $\begin{array}{c}23.85 \\
{[20.28,27.42]}\end{array}$ & 3.85 \\
\hline Organizing reflections about learning with digital tools & $\begin{array}{c}4.23 \\
{[2.53,5.93]}\end{array}$ & $\begin{array}{c}24.42 \\
{[20.82,28.03]}\end{array}$ & $\begin{array}{c}51.73 \\
{[47.59,55.87]}\end{array}$ & $\begin{array}{c}16.15 \\
{[13.06,19.25]}\end{array}$ & 3.46 \\
\hline Reflection about role in own learning & $\begin{array}{c}2.69 \\
{[1.33,4.06]}\end{array}$ & $\begin{array}{c}21.35 \\
{[17.91,24.79]}\end{array}$ & $\begin{array}{c}57.12 \\
{[53.05,61.18]}\end{array}$ & $\begin{array}{c}15.19 \\
{[12.17,18.21]}\end{array}$ & 3.65 \\
\hline Recording reflections about own learning & $\begin{array}{c}6.54 \\
{[4.46,8.62]}\end{array}$ & $\begin{array}{c}36.54 \\
{[32.52,40.56]}\end{array}$ & $\begin{array}{c}43.46 \\
{[39.34,47.58]}\end{array}$ & $\begin{array}{c}9.81 \\
{[7.30,12.31]}\end{array}$ & 3.65 \\
\hline
\end{tabular}

In this Table, $\mathrm{N}=877$, (1) $\mathrm{CI} 95 \%$ and (2) $\mathrm{NA}=$ No answer

Table 3. Relationship between actions for self-regulated learning in PLEs

\begin{tabular}{|c|c|c|c|c|c|c|}
\hline \multirow{2}{*}{ Actions } & \multicolumn{5}{|c|}{ Kendall's coefficient ${ }^{(1)}$ and confidence intervals ${ }^{(2)}$} & \multirow[b]{2}{*}{6} \\
\hline & 1 & 2 & 3 & 4 & 5 & \\
\hline \multicolumn{7}{|l|}{1 Documenting the personal learning process } \\
\hline 2 Using a personal blog to delve into ideas or concepts of the course & $\begin{array}{c}.35 \\
{[.29, .41]}\end{array}$ & & & & & \\
\hline 3 Recording reflections on own learning & $\begin{array}{c}.39 \\
{[.33, .45]}\end{array}$ & $\begin{array}{c}.30 \\
{[.24, .35]}\end{array}$ & & & & \\
\hline 4 Reflecting on role on own learning & & & $\begin{array}{c}38 \\
{[.32, .44]}\end{array}$ & & & \\
\hline 5 Valuing teacher's evaluations or suggestions for improving their work & & & & $\begin{array}{c}.30 \\
{[.24, .35]}\end{array}$ & & \\
\hline \multicolumn{7}{|l|}{$\begin{array}{l}6 \text { Using tools from outside of the University for exchanging information with } \\
\text { classmates }\end{array}$} \\
\hline 7 Organizing reflections on own learning using digital tools & $\begin{array}{c}.31 \\
{[.25, .37]}\end{array}$ & $\begin{array}{c}.25 \\
{[.20, .30]}\end{array}$ & $\begin{array}{c}.55 \\
{[.49, .61]}\end{array}$ & $\begin{array}{c}.51 \\
{[.45, .57]}\end{array}$ & & \\
\hline 8 Adapting the tools of University LMS platform to learning goals & $\begin{array}{c}.43 \\
{[.37, .49]}\end{array}$ & $\begin{array}{c}.36 \\
{[.31, .42]}\end{array}$ & $\begin{array}{c}.32 \\
{[.26, .38]}\end{array}$ & $\begin{array}{c}28 \\
{[.23, .34]}\end{array}$ & & \\
\hline 9 Using digital tools for representing ideas in various forms & & & & & $\begin{array}{c}.39 \\
{[.33, .45]}\end{array}$ & $\begin{array}{c}.31 \\
{[.25, .37]}\end{array}$ \\
\hline $\begin{array}{l}10 \text { Using tools of University LMS platforms to send information to persons } \\
\text { not participating in the course }\end{array}$ & & & & & & $\begin{array}{c}.36 \\
{[.31, .42]}\end{array}$ \\
\hline $\begin{array}{l}11 \text { Using tools of University LMS platforms to receive information from } \\
\text { classmates }\end{array}$ & & & & & & $\begin{array}{c}.37 \\
{[.32, .43]}\end{array}$ \\
\hline $\begin{array}{l}12 \text { Using PLE tools to send information to persons not participating in the } \\
\text { course }\end{array}$ & & & & & & $\begin{array}{c}.35 \\
{[.29, .41]}\end{array}$ \\
\hline
\end{tabular}

In this Table, $\mathrm{N}=877$, (1) $\mathrm{p}<0,01$, two-tailed, and (2) CI 95\% 


\subsection{Self-regulated learning achievements in PLEs}

Table 4 shows that students achieved positive results in self-regulated learning during the performance phase. Students complied with the deadlines for handing in their work $(96.73 \%)$, worked on their tasks in an organized manner $(90.58 \%)$, defined their personal learning goals $(87.88 \%)$, and carried out extracurricular activities proposed by teachers (91.92\%).

Students took advantage of the available technological tools, both those of the University $(89.42 \%)$ and external (94.62\%). However, there was a significant percentage of students who did not successfully use the information obtained from persons who were not participating in the course $(28.65 \%)$.
Most students adequately apportioned their time during their performance phase; however, there was a considerable percentage of students who did not reach this achievement (21.54\%); there was also a group of students who could not read all the material assigned by teachers.

Figure 3 shows that the students were able to reflect on their learning, an achievement that corresponds to the reflection phase. However, in this phase, there was a very significant percentage of students who neither carried out complementary research $(51.37 \%)$ nor deepened their knowledge of the course's subject matter (38.27\%).

Table 4. Achievements during performance and reflection phases of the self-regulated learning process in PLEs

\begin{tabular}{|c|c|c|c|c|c|}
\hline \multirow{2}{*}{ Achievements } & \multicolumn{4}{|c|}{ Relative frequencies with confidence intervals ${ }^{(1)}$} & \multirow{2}{*}{$\begin{array}{c}\% \\
N^{(2)}\end{array}$} \\
\hline & Strongly disagree & Disagree & Agree & Strongly agree & \\
\hline \multicolumn{6}{|l|}{ Performance phase } \\
\hline Complied with deadlines for handing in work & $\begin{array}{c}1.15 \\
{[0.24,2.07]}\end{array}$ & $\begin{array}{c}1.54 \\
{[0.48,2.59]}\end{array}$ & $\begin{array}{c}23.27 \\
{[19.65,26.89]}\end{array}$ & $\begin{array}{c}73.46 \\
{[69.71,77.22]}\end{array}$ & 0.58 \\
\hline $\begin{array}{l}\text { Used technological tools from outside the University success- } \\
\text { fully }\end{array}$ & $\begin{array}{c}0.96 \\
{[0.13,1.80]}\end{array}$ & $\begin{array}{c}3.46 \\
{[1.90,5.02]}\end{array}$ & $\begin{array}{c}29.81 \\
{[25.90,33.71]}\end{array}$ & $\begin{array}{c}64.81 \\
{[60.76,68.86]}\end{array}$ & 0.96 \\
\hline $\begin{array}{l}\text { Carried out the activities proposed by the teacher as extracurri- } \\
\text { cular activities on time }\end{array}$ & $\begin{array}{c}0.96 \\
{[0.13,1.80]}\end{array}$ & $\begin{array}{c}6.35 \\
{[4.26,8.43]}\end{array}$ & $\begin{array}{c}40.96 \\
{[36.76,45.16]}\end{array}$ & $\begin{array}{c}50.96 \\
{[46.70,55.22]}\end{array}$ & 0.77 \\
\hline Worked on tasks in an organized manner & $\begin{array}{c}0.77 \\
{[0.02,1.52]}\end{array}$ & $\begin{array}{c}7.50 \\
{[5.25,9.75]}\end{array}$ & $\begin{array}{c}55.58 \\
{[51.36,59.79]}\end{array}$ & $\begin{array}{c}35.00 \\
{[30.94,39.06]}\end{array}$ & 1.15 \\
\hline $\begin{array}{l}\text { Took advantage of the technological tools of the University } \\
\text { platform }\end{array}$ & $\begin{array}{c}0.58 \\
{[0.00,1.22]}\end{array}$ & $\begin{array}{c}9.04 \\
{[6.59,11.49]}\end{array}$ & $\begin{array}{c}57.50 \\
{[53.30,61.70]}\end{array}$ & $\begin{array}{c}31.92 \\
{[27.94,35.90]}\end{array}$ & 0.96 \\
\hline Was able to read all the material proposed by the teacher & $\begin{array}{c}1.35 \\
{[0.36,2.33]}\end{array}$ & $\begin{array}{c}20.19 \\
{[16.76,23.63]}\end{array}$ & $\begin{array}{c}56.15 \\
{[51.93,60.38]}\end{array}$ & $\begin{array}{c}21.54 \\
{[18.02,25.05]}\end{array}$ & 0.77 \\
\hline $\begin{array}{l}\text { Took advantage of information obtained from persons not } \\
\text { participating in the course }\end{array}$ & $\begin{array}{c}4.62 \\
{[2.82,6.41]}\end{array}$ & $\begin{array}{c}24.04 \\
{[20.38,27.69]}\end{array}$ & $\begin{array}{c}52.69 \\
{[48.44,56.95]}\end{array}$ & $\begin{array}{c}17.88 \\
{[14.61,21.16]}\end{array}$ & 0.77 \\
\hline Defined personal learning goals & $\begin{array}{c}0.96 \\
{[0.13,1.79]}\end{array}$ & $\begin{array}{c}20.96 \\
{[17.49,24.43]}\end{array}$ & $\begin{array}{c}63.08 \\
{[59.01,67.15]}\end{array}$ & $\begin{array}{c}13.65 \\
{[10.73,16.58]}\end{array}$ & 1.35 \\
\hline Was able to apportion time to carry out tasks & $\begin{array}{c}1.15 \\
{[0.24,2.07]}\end{array}$ & $\begin{array}{c}20.38 \\
{[16.94,23.83]}\end{array}$ & $\begin{array}{c}64.42 \\
{[60.36,68.48]}\end{array}$ & $\begin{array}{c}13.08 \\
{[10.20,15.96]}\end{array}$ & 0.96 \\
\hline \multicolumn{6}{|l|}{ Reflection phase } \\
\hline Reflected on acquired knowledge & $\begin{array}{c}1.15 \\
{[0.24,2.07]}\end{array}$ & $\begin{array}{c}20.38 \\
{[16.94,23.83]}\end{array}$ & $\begin{array}{c}64.42 \\
{[60.36,68.48]}\end{array}$ & $\begin{array}{c}13.08 \\
{[10.20,15.96]}\end{array}$ & 0.96 \\
\hline Delved into knowledge pertaining to course's subject matter & $\begin{array}{c}4.81 \\
{[2.98,6.64]}\end{array}$ & $\begin{array}{c}33.46 \\
{[29.44,37.48]}\end{array}$ & $\begin{array}{c}52.50 \\
{[48.26,56.74]}\end{array}$ & $\begin{array}{c}8.08 \\
{[5.75,10.40]}\end{array}$ & 1.15 \\
\hline $\begin{array}{l}\text { Carried out complementary investigations pertaining to course } \\
\text { subject matter }\end{array}$ & $\begin{array}{c}6.73 \\
{[4.59,8.88]}\end{array}$ & $\begin{array}{c}44.62 \\
{[40.37,48.86]}\end{array}$ & $\begin{array}{c}40.77 \\
{[36.57,44.97]}\end{array}$ & $\begin{array}{c}7.12 \\
{[4.91,9.32]}\end{array}$ & 0.77 \\
\hline
\end{tabular}

In this Table, $\mathrm{N}=877$, (1) CI 95\% and (2) NA = No answer

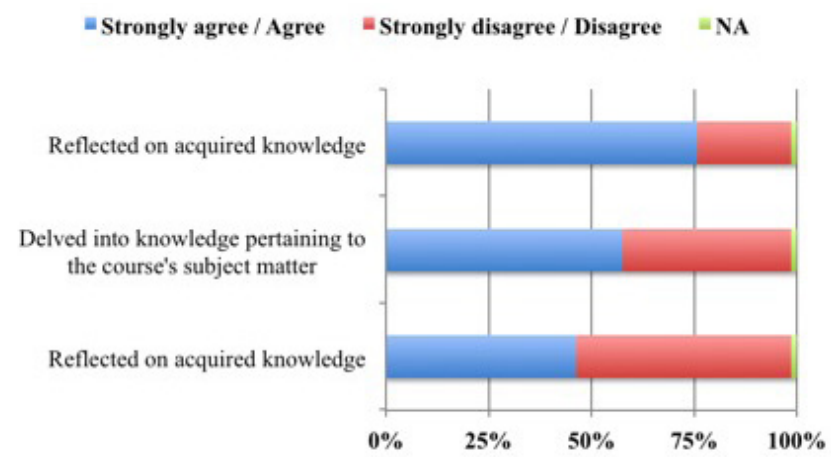

Figure 3. Achievements during the reflection phase of the self-regulated learning process in PLEs 


\subsection{Relationships between student achievements}

The correlations presented in Table 5 indicate that the material proposed by teachers encouraged students to deepen their knowledge of subjects covered in courses. These correlations also allow the identification of three subgroups of students called organizers, deepeners, and non-deepeners.

Members of the organizer student subgroup worked in an organized manner on their tasks, carried out the activities proposed by teachers on time, complied with deadlines for handing in their work, and apportioned their time appropriately; they were very successful in all aspects at the same time. The existence of this student subgroup is shown by the fact that the achievements mentioned previously are present at high relative frequencies and have high positive correlations.

Secondly, there was a deepener subgroup, composed of students who delved into knowledge, carried out complementary research on the subject matters addressed in their courses, and reflected on the knowledge they acquired. Finally, and in contrast, there was a student subgroup, which did not obtain any of these three achievements, called the non-deepener subgroup. The existence of these two subgroups is deduced by the high correlation between these three achievements (see Table 5), and because the frequencies indicate that there are significant percentages of students who have obtained these achievements, and also of students who have not done so (see Table 4).

\subsection{Effects of actions on self-regulated learning achievement in PLEs}

The Kruskal-Wallis analysis presented in Table 6 shows relevant results in the reflection phase. For instance, it indicates that the subject's reflection about their role on their own learning had a statistically significant effect on reflection during learning. The figure of 0.36 for the extent of the effect shown in the Table indicates that, in this case, variation in the value of this action influences the variation of this achievement by $13 \%$, at a $95 \%$ level of confidence.

The subject's reflection about their own role on their learning also had an influence $(9 \%)$ on undertaking of complementary research about the course's subject matter. Likewise, the use of digital tools for organizing thoughts about learning had a $9 \%$ influence on these reflections, which is an indicator of the weight these tools had during the reflection phase.

Based on the results presented in Table 6, it may be concluded that the exchange of information with classmates using tools from outside the University had a $9 \%$ influence on the successful use of these tools. This means that part of the information they exchanged with classmates was used to support the successful use of external tools. From the Kruskall-Wallis analysis it may also be concluded that documentation of the personal learning process encouraged delving into the knowledge on the course's subject matter by approximately $10 \%$.

Table 5. Relationship between achievements in self-regulated learning in PLEs, performance and reflection phases

\begin{tabular}{|c|c|c|c|c|}
\hline \multirow[t]{2}{*}{ Actions } & \multicolumn{4}{|c|}{$\begin{array}{c}\text { Kendall's coefficient }^{(1)} \text { and confidence } \\
\text { intervals }^{(2)}\end{array}$} \\
\hline & 1 & 2 & 3 & 4 \\
\hline \multicolumn{5}{|l|}{1 Worked on tasks in an organized manner } \\
\hline $\begin{array}{l}2 \text { Carried out activities proposed by the teacher for extracurricular work on } \\
\text { time }\end{array}$ & $\begin{array}{c}.51 \\
{[.45, .57]}\end{array}$ & & & \\
\hline 3 Delved into knowledge about the subject matter of the course & $\begin{array}{l}.20 \\
{[.15, .26]}\end{array}$ & & & \\
\hline 4 Reflected on acquired knowledge & & & $\begin{array}{c}.32 \\
{[.26, .38]}\end{array}$ & \\
\hline 5 Complied with deadlines for handing in work & $\begin{array}{c}.31 \\
{[.25, .37]}\end{array}$ & $\begin{array}{c}.47 \\
{[.41, .52]}\end{array}$ & & \\
\hline 6 Achieved an adequate apportioning of time for carrying out tasks & $\begin{array}{c}.43 \\
{[.37, .49]}\end{array}$ & $\begin{array}{l}.35 \\
{[.29, .41]}\end{array}$ & $\begin{array}{l}.21 \\
{[.15, .26]}\end{array}$ & $\begin{array}{c}.25 \\
{[.19, .30]}\end{array}$ \\
\hline 7 Was able to read all the material proposed by teacher & & & $\begin{array}{c}.31 \\
{[.25, .37]}\end{array}$ & $\begin{array}{c}.24 \\
{[.18, .30]}\end{array}$ \\
\hline 8 Carried out complementary investigations on the subject matter of the course & & & $\begin{array}{c}.45 \\
{[.39, .51]}\end{array}$ & $\begin{array}{c}.33 \\
{[.27, .39]}\end{array}$ \\
\hline
\end{tabular}

In this Table, $\mathrm{N}=877$, (1) p <0,01, two-tailed, and (2) CI 95\% 
Table 6. Effect of actions on achievements in the self-regulated learning process in PLEs

\begin{tabular}{|c|c|c|}
\hline \multicolumn{3}{|c|}{ Results using the Kruskal-Wallis test for variance analysis with size of the effect and confidence intervals } \\
\hline \multirow[b]{2}{*}{ Actions } & TE $95 \%$ & \multirow[b]{2}{*}{ Achievements } \\
\hline & IC $95 \%$ & \\
\hline Using tools from outside the University for exchanging information with classmates & $\begin{array}{c}30 \\
{[.21, .39]} \\
\end{array}$ & $\begin{array}{l}\text { Used technological tools from outside of the } \\
\text { University successfully }\end{array}$ \\
\hline Documenting the personal learning process & $\begin{array}{c}.31 \\
{[.22, .40]}\end{array}$ & $\begin{array}{l}\text { Delved into knowledge of the subject matters } \\
\text { of the course }\end{array}$ \\
\hline \multirow{2}{*}{ Reflecting on role in own learning } & $\begin{array}{c}.30 \\
{[.21, .38]}\end{array}$ & $\begin{array}{l}\text { Carried out complementary investigations on } \\
\text { the subject matter of the course }\end{array}$ \\
\hline & $\begin{array}{c}.36 \\
{[.28, .45]}\end{array}$ & \multirow{2}{*}{ Reflected on acquired knowledge } \\
\hline Organizing reflections on learning with digital tools & $\begin{array}{c}.30 \\
{[.22, .39]}\end{array}$ & \\
\hline
\end{tabular}

\section{DISCUSSION OF RESULTS}

The most popular devices used were portable computers, followed by smart phones. This indicates that students - largely women - had ubiquitous access to some of the tools in their PLEs (Taraghi, 2012). A great majority of students considered that they had successfully used the tools in their personal learning environment for exchanging information with persons not participating in courses. On the other hand, students perceived that information exchange with classmates was successful, using both the resources available in University LMS platforms and those external to the University. Some tools of the LMS platforms were adapted by students to their learning goals; however, there was a proportion of students (39.23\%) who had not made any adaptation.

The significant correlation between the action of exchanging information with classmates using external tools, and the action of using university LMS tools, indicates that the external tools did not compete with the LMS tools, but rather complemented them. Likewise, the revealing correlation between the use of PLE tools to send information to classmates and the use of tools external to the University for exchanging information with classmates, indicates that information exchange with persons not participating in the courses complemented information exchange with classmates.

Students asked for help from their teachers, valued their evaluations and suggestions, and showed critical thinking about their teaching strategies. The correlations between variables indicate that teacher suggestions and evaluations were related to actions by students regarding the use of digital tools and the recording of their reflections on their own learning. This indicates that the teachers probably encouraged these actions.

The data indicates that a majority of students reflected on the role they have in their own learning, an important proportion used digital tools to organize their reflections about learning (67.88\%), and approximately half of them recorded these thoughts. These three actions are strongly correlated $(t>.38)$, indicating the importance of PLE digital tools during the phase of reflection.

There were significant correlations $(t>.30)$ between the actions of recording reflections about the students own learning, using a blog to delve into ideas or concepts of the course, documenting the personal learning process, and adapting LMS tools to learning goals. This reinforces the idea that reflection about learning is related to the use of PLE technological tools; it furthermore indicates that personal blogs were being used to document and record the learning process. It is possible that the construction of the blog and the registration of reflections in general were being carried out using some LMS platforms, since adapting LMS tools to learning goals was markedly related to documentation of the learning process, the recording of reflections, and the use of the blog to delve into ideas. This suggests that University LMS platforms played a role in metacognition, and that they included blogs used by some students for this purpose. Future investigations may shed further light on these ideas.

The importance of PLE digital tools for self-regulated learning was clear; a great majority of students $(85.39 \%)$ use them for expressing their ideas in various forms. Based on the frequency analysis of self-regulated learning achievements, and of the correlations between them, three subgroups of students were identified in the population. The organizer subgroup consisted of students who worked in an organized manner on their tasks, carried out the activities proposed by teachers on time, complied with deadlines for handing in their work, and apportioned their time appropriately.

On the other hand, there was a deepener subgroup, composed of students who delved into knowledge, carried out complementary research on the subject matters addressed in their courses, and reflected on the knowledge they acquired. Finally, there was a student subgroup, which did not obtain any of these three achievements, called the non-deepener subgroup. The possible relationships between students of the organizer subgroup and those of the other two subgroups may be the basis for further investigations. It would also be interesting to study in more depth the characterization of these subgroups.

Variance analyses show that students' reflections about their own role in learning has an influence, not only on metacognitive achievements, but also in explaining their cognitive achievements, such as the undertaking of complementary research projects about course subject matters. This fact highlights the role of individuals in their own learning process, and is consistent with the cyclical nature of self-regulated learning. Therefore, individuals play a key role in their own learning process, and the actions they take during the reflection phase have an influence on their self-regulated learning achievements in this phase as well as in others.

Part of the success in the use of tools from outside the University may be explained based on information exchange between classmates using these tools. Theory indicates that social influence on the individual self-regulation process is complex and multidimensional; these results represent an example of such social influence. In his investigations, Zimmerman (2008) pointed out that a strategy for a person to increase his or her self-regulated learning abilities consists of consulting or observing other 
individuals' models which are considered to be efficient, and imitating these models while receiving social feedback.

Finally, the analyses of variance show that the action of documenting the learning process has an influence on the deepness of thematic knowledge achieved by students. This is a clear example of the influence of metacognitive actions on cognitive processes.

\section{REFERENCES}

Archee, R. (2012). Reflections on Personal Learning Environments: Theory and Practice. Procedia - Social and Behavioral Sciences, 55, 419-428. doi:10.1016/j. sbspro.2012.09.520

Buchem, I., \& Tur, G. (2014). Super users constructing their PLEs: Exploring gender differences. En E. Baldone (Presidency), The PLE Conference 2014. Congress held in Tallinn, Estonia.

Bullock, S. M. (2013). Using digital technologies to support Self-Directed Learning for preservice teacher education. Curriculum Journal, 24(1), 103-120. doi:10.1 080/09585176.2012.744695

Chatti, M. A., Dakova, S., Thüs, H., \& Schroeder, U. (2013). Tag-Based Collaborative Filtering Recommendation in Personal Learning Environments. IEEE Transactions on learning technologies, 6(4), 337-349. doi:10.1109/TLT.2013.23

Chaves, E., Trujillo, J. M., \& López, J. A. (2015). Autorregulación del aprendizaje en entornos personales de aprendizaje en el Grado de Educación Primaria de la Universidad de Granada, España. Formación Universitaria, 8(4), 63-76. doi: $10.4067 / \mathrm{S} 0718-50062015000400008$

Chaves, E., Trujillo, J. M., \& López, J. A. (2016). Acciones para la autorregulación del aprendizaje en entornos personales. Píxel-Bit. Revista de Medios y Educación, 48, 67-83. doi:10.12795/pixelbit.2016.i48.05

Cheng, G., \& Chau, J. (2013). Exploring the relationship between students' self-regulated learning ability and their ePortfolio achievement. The Internet and Higher Education, 17, 9-15. doi:10.1016/j.iheduc.2012.09.005

Cho, K., \& Cho, M. H. (2013). Training of self-regulated learning skills on a social network system. Social Psychology of Education, 16(4), 617-634. doi:10.1007/ s11218-013-9229-3

Cohen, J. (1992). Quantitative methods in psychology: A power primer. Psychological Bulletin, 112(1), 155-159. doi:10.1037/0033-2909.112.1.155

Dabbagh, N., \& Kitsantas, A. (2012). Personal Learning Environments, social media, and self-regulated learning: A natural formula for connecting formal and informal learning. The Internet and Higher Education, 15(1), 3-8. doi:10.1016/j. iheduc.2011.06.002

Ebner, M., \& Taraghi, B. (2010). Personal learning environment for higher education. A first prototype. In Proceedings of world conference on educational multimedia, hypermedia and telecommunications (pp. 1158-1166). Chesapeake, VA: AACE.

Fiedler, S., \& Väljataga, T. (2011). Personal Learning Environments. International Journal of Virtual and Personal Learning Environments, 2(4), 1-11. doi:10.4018/ jvple.2011100101

Fiedler, S., \& Väljataga, T. (2013). Personal learning environments: a conceptual landscape revisited. eLearning Papers, 35, 1-16. doi:10.4018/978-1-4666-24672.ch014

Hadwin, A. F., Oshige, M., Gress, C. L. Z., \& Winne, P. H. (2010). Innovative ways for using gStudy to orchestrate and research social aspects of self-regulated learning. Computers in Human Behavior, 26(5), 794-805. doi:10.1016/j. chb.2007.06.007

Holt, L., \& Brockett, R. G. (2012). Self direction and factors influencing technology use: Examining the relationships for the 21 st century workplace. Computers in Human Behavior, 28(6), 2075-2082. doi:10.1016/j.chb.2012.06.011

Jin, P., \& Low, R. (2009). Enhancing motivation and self-regulated learning in multimedia environments. In R. D. Koo, B. C. Choi, M. R. D. Lucas, \& T. C. Chan (Eds.), Education policy, reform, and school innovations in the Asia-Pacific Region (pp. 525-547). Hong Kong: Association for Childhood Education International/Hong Kong y Macao (ACEI-HKM).

Johnson, M. W., \& Sherlock, D. (2014). Beyond the Personal Learning Environment: attachment and control in the classroom of the future. Interactive Learning Environments, 22(2), 146-164. doi:10.1080/10494820.2012.745434

Kruskal, W. H., \& Wallis, W. A. (1952). Use of ranks in one-criterion variance analysis. Journal of the American Statistical Association, 47, 583-621. doi:10.1080 /01621459.1952.10483441

Leech, N., Barrett, K., \& Morgan, G. (2011). IBM SPSS for intemediate statistics, use and interpretation. New York: Taylor and Francis Group, LLC.

Osterlind, S. J. (1989). Constructing tests items. Boston: Kluwer Academic Publishers. doi:10.1007/978-94-009-1071-3

Ros, S., Hernández, R., Robles-Gómez, A., Caminero, A. C., Tobarra, L., \& Ruiz, E. S. (2013). Open Service-Oriented Platforms for Personal Learning Environments. IEEE internet computing, 27-31. doi:10.1109/mic.2013.73
Schunk, D. H., \& Zimmerman, B. (2003). Self-regulation and learning. In W. M Reynolds, \& G. E. Miller (Eds.), Handbook of psychology (Vol. 7): Educational psychology (pp. 59-78). Hoboken, NJ: Wiley. doi:10.1002/0471264385. wei0704

Strahan, R. F. (1982). Assessing magnitude of effect from rank-order correlation coeffients. Educational and Psychological Measurement, 42, 763-765. doi: $10.1177 / 001316448204200306$

Taraghi, B. (2012). Ubiquitous Personal Learning Environment (UPLE). International Journal of Emerging Technologies in Learning (iJET), 7, 7-14. doi:10.1109/ icl.2012.6402139

Usher, E. L., \& Pajares, F. (2008). Self-efficacy for self-regulated learning: A validation study. Educational and Psychological Measurement, 68, 443-463. doi: $10.1177 / 0013164407308475$

Valtonen, T., Hacklin, S., Dillon, P., Vesisenaho, M., Kukkonen, J., \& Hietanen, A. (2012). Perspectives on personal learning environments held by vocational students. Computers \& Education, 58(2), 732-739. doi:10.1016/j. compedu.2011.09.025

Zimmerman, B. J. (2008). Investigating self-regulation and motivation: Historical background, methodological development, and future prospects. American Educational Research Journal, 45(1), 166-183. doi:10.3102/0002831207312909

Zimmerman, B. J., \& Schunk, D. H. (Eds.). (1989). Self-regulated learning and academic achievement: Theory, research and practice. New York: Springer. doi:10.1007/978-1-4612-3618-4

Zimmerman, B. J., \& Cleary, T. J. (2009). Motives to self-regulate learning. In K. R. Wentzel, \& A. Wigfield (Eds.), Handbook of motivation at school (pp. 247-264) New York, NY: Routledge.

How to cite this article: Chaves, E., Trujillo, J. M., López, J. A., \&

Sola, T. (2017). Actions and achievements of self-regulated learning in personal environments. Research on students participating in the Graduate Program in Preschool Education at the University of Granada. Journal of New Approaches in Educational Research, 6(2), 135-143. doi: 10.7821/naer.2017.7.236 